\title{
Hydriding and Dehydriding Features of a Titanium-Added Magnesium Hydride Composite
}

\author{
Eunho CHOI ${ }^{1}$, Myoung Youp SONG ${ }^{2 *}$ \\ ${ }^{1}$ Department of Materials Engineering, Graduate School, Jeonbuk National University, 567 Baekje-daero Deokjin-gu \\ Jeonju, 54896, Republic of Korea \\ ${ }^{2}$ Division of Advanced Materials Engineering, Hydrogen \& Fuel Cell Research Center, Engineering Research Institute, \\ Jeonbuk National University, 567 Baekje-daero Deokjin-gu Jeonju, 54896, Republic of Korea
}

crossref http://dx.doi.org/10.5755/j01.ms.26.2.22299

Received 14 December 2018; accepted 01 February 2019

\begin{abstract}
Magnesium has excellent hydrogen-storage properties except low hydriding and dehydriding rates. In the present work, titanium (Ti) was chosen as an additive to increase the hydriding rate of $\mathrm{Mg}$ and the dehydriding rate of $\mathrm{MgH}_{2} .15 \mathrm{wt} . \%$ Ti was added to $\mathrm{MgH}_{2}$ by milling in hydrogen (reactive mechanical grinding). The hydriding and dehydriding features of the Ti-added $\mathrm{MgH}_{2}$ composite (named $85 \mathrm{MgH}_{2}+15 \mathrm{Ti}$ ) were investigated. At the first cycle $(\mathrm{n}=1), 85 \mathrm{MgH}_{2}+15 \mathrm{Ti}$ absorbed $2.96 \mathrm{wt} . \% \mathrm{H}$ for $2.5 \mathrm{~min}$ and $5.51 \mathrm{wt} \% \mathrm{H}$ for $60 \mathrm{~min}$ at $593 \mathrm{~K}$ in $12 \mathrm{bar}_{2}$, having an effective hydrogenstorage capacity of 5.51 wt. $\%$. $\beta-\mathrm{MgH}_{2}, \gamma-\mathrm{MgH}_{2}, \mathrm{TiH}_{1.924}, \mathrm{MgO}$, and $\mathrm{MgTi}_{2} \mathrm{O}_{4}$ were formed during reactive mechanical grinding. Reactive mechanical grinding of $\mathrm{MgH}_{2}$ with $\mathrm{Ti}$ is believed to create imperfections, produce cracks and clean surfaces, and decrease particle sizes. The phases formed during reactive mechanical grinding and their pulverization during reactive mechanical grinding are believed to make these effects stronger.

Keywords: hydrogen-storage materials, milling in hydrogen, hydriding and dehydriding rates, hydrogen-storage capacity titanium-added magnesium hydride.
\end{abstract}

\section{INTRODUCTION}

Magnesium (Mg) has excellent hydrogen-storage features, but it has low hydriding and dehydriding rates. To increase the reaction rates of $\mathrm{Mg}$ with hydrogen, many researches were carried out by adding added to $\mathrm{Mg}$ or $\mathrm{MgH}_{2}$ transition metals [1-4], rare-earth metals [5], graphite [6,7], or intermetallic compounds [8-10] have been added to $\mathrm{Mg}$ or $\mathrm{MgH}_{2}$.

Rizo-Acosta et al. [11] added different amounts of $\mathrm{Ti}$ to magnesium to form $\mathrm{MgH}_{2}-\mathrm{TiH}_{2}$ nanocomposites by reactive ball milling under hydrogen gas. On increasing $\mathrm{Ti}$ amount, hydriding and dehydriding kinetics were enhanced leading to a higher reversibility for hydrogen storage with the $\mathrm{MgH}_{2}$ phase. The highest reversible capacity (4.9 wt.\% $\mathrm{H})$ was obtained for the lowest $\mathrm{TiH}_{2}$ content $(\mathrm{y}=0.025)$. Sohn et al. [12] reported that the $\mathrm{MgH}_{2}$ doped with $\mathrm{TiH}_{2}$ by high-energy milling displayed substantially reduced apparent activation energy and significantly faster kinetics, compared with similarly milled $\mathrm{MgH}_{2}$ without $\mathrm{TiH}_{2}$ doping. Daryani et al. [13] investigated the co-effects of Ti-based catalysts $\left(\mathrm{TiH}_{2}\right.$ and $\mathrm{TiO}_{2}$ particles) on hydrogen desorption kinetics of nanostructured magnesium hydride. The samples were prepared by high-energy ball milling. Evaluation of the absorption/desorption properties revealed that the addition of the Ti-based catalysts significantly improved the hydrogen storage performance of $\mathrm{MgH}_{2}$. A decrease in the decomposition temperature (as high as $100 \mathrm{~K}$ ) was attained after co-milling of $\mathrm{MgH}_{2}$ with the Tibased catalysts.

\footnotetext{
${ }^{*}$ Corresponding author. Tel.: +82-63-270-2379; fax: +82-63-270-2386.

E-mail address: songmy@jbnu.ac.kr (M.Y. Song)
}

In the present work, titanium (Ti) was chosen as an additive to improve the hydriding and dehydriding features of $\mathrm{MgH}_{2}$. 15 wt.\% Ti was added to $\mathrm{MgH}_{2}$ by milling in hydrogen (reactive mechanical grinding). The hydriding and dehydriding features of the Ti-added $\mathrm{MgH}_{2}$ composite (named $\mathrm{MgH}_{2}-15 \mathrm{Ti}$ ) were investigated.

\section{EXPERIMENTAL DETAILS}

We used $\mathrm{MgH}_{2}$ powder (magnesium hydride, hydrogen storage grade, Sigma Aldrich.) and titanium (3.25 mesh, $99.5 \%$ metal basis, Alfa Aesar) as starting materials.

Reactive mechanical grinding to prepare a $85 \mathrm{MgH}_{2}+15 \mathrm{Ti}$ sample, which has a composition of 85 wt. $\% \mathrm{Mg}+15$ wt. $\% \mathrm{Ti}$, was performed in a planetary ball mill (Planetary Mono Mill; Pulverisette 6, Fritsch). Mixtures with the desired compositions $(8 \mathrm{~g})$ were milled in a hermetically sealed stainless steel container with 105 hardened steel balls (total weight $360 \mathrm{~g}$ ). All sample handling was performed in a glove box under Ar in order to prevent oxidation. The disc revolution speed was $250 \mathrm{rpm}$. The mill container with a volume of $250 \mathrm{~mL}$ was then filled with high purity hydrogen gas ( 12 bar). Milling was performed for $6 \mathrm{~h}$, refilling hydrogen up to $\sim 12$ bar every two hours [14-17].

The absorbed or released hydrogen quantity, as the reaction time elapses, was measured in nearly constant hydrogen pressures (in 12 bar $\mathrm{H}_{2}$ for hydriding and in 1.0 bar $\mathrm{H}_{2}$ for dehydriding) with the Sieverts' type hydriding and dehydrding apparatus described previously [18-22]. $0.5 \mathrm{~g}$ of the samples was used for these measurements. 
Samples after reactive mechanical grinding and after hydriding-dehydrding cycling were analysed by X-ray diffraction (XRD) with $\mathrm{Cu} \mathrm{K} \alpha$ radiation, using a Rigaku D/MAX 2500 powder diffractometer. The microstructures of the powders were observed using a JSM-5900 scanning electron microscope (SEM) operated at $20 \mathrm{kV}$.

\section{RESULTS AND DISCUSSION}

Fig. 1 shows the variation in $\mathrm{H}_{\mathrm{a}}$ versus $\mathrm{t}$ curve with cycle number, $\mathrm{n}$, at $573 \mathrm{~K}$ in 12 bar $\mathrm{H}_{2}$ for $85 \mathrm{Mg}$ $\mathrm{H}_{2}+15 \mathrm{Ti}$. At $\mathrm{n}=1$, the initial hydriding rate is quite high and the quantity of hydrogen absorbed for $60 \mathrm{~min}, \mathrm{H}_{\mathrm{a}}$ (60 min), is quite large. At $\mathrm{n}=1$, the hydriding rate decreases gradually as the reaction time elapses and is very low after $20 \mathrm{~min}$. As $\mathrm{n}$ increases from one to four, the initial hydriding rate and $\mathrm{H}_{\mathrm{a}}(60 \mathrm{~min})$ decrease in general. The general decreases in the initial hydriding rate and $\mathrm{H}_{\mathrm{a}}$ (60 min) with the increase in the cycle number are believed to be due to coalescence of particles since the sample was maintained at the relatively high temperature $573 \mathrm{~K}$ during hydriding-dehydriding cycling. At $\mathrm{n}=1,85 \mathrm{MgH}_{2}+15 \mathrm{Ti}$ absorbs $1.58 \mathrm{wt} . \% \mathrm{H}$ for $2.5 \mathrm{~min}, 2.67 \mathrm{wt} . \% \mathrm{H}$ for $10 \mathrm{~min}$, and $3.44 \mathrm{wt} . \% \mathrm{H}$ for $60 \mathrm{~min}$. At $\mathrm{n}=4,85 \mathrm{MgH}_{2}+15 \mathrm{Ti}$ absorbs $1.40 \mathrm{wt} . \% \mathrm{H}$ for $2.5 \mathrm{~min}, 2.44 \mathrm{wt} . \% \mathrm{H}$ for $10 \mathrm{~min}$, and $3.21 \mathrm{wt} . \% \mathrm{H}$ for $60 \mathrm{~min}$. Table 1 shows the variation of $\mathrm{H}_{\mathrm{a}}$ with $\mathrm{t}$ at $573 \mathrm{~K}$ in 12 bar $\mathrm{H}_{2}$ at $\mathrm{n}=1 \sim 4$ for $85 \mathrm{MgH}_{2}+15 \mathrm{Ti}$.

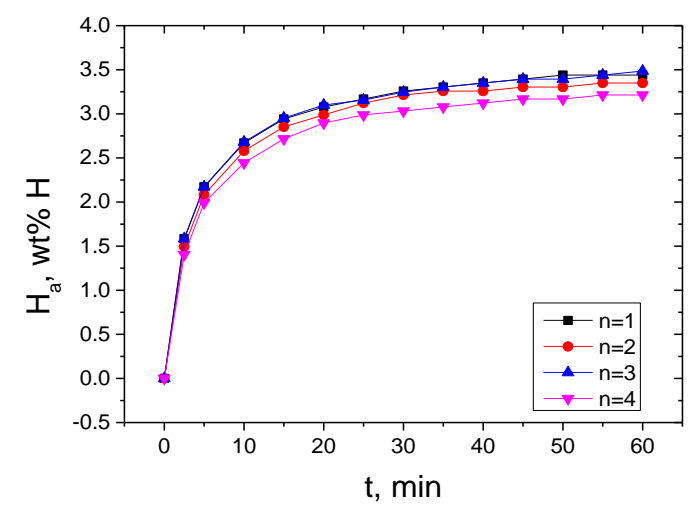

Fig. 1. Variation in $\mathrm{H}_{\mathrm{a}}$ versus $\mathrm{t}$ curve with cycle number, n, at $573 \mathrm{~K}$ in 12 bar $\mathrm{H}_{2}$ for $85 \mathrm{MgH}_{2}+15 \mathrm{Ti}$

Table 1. Variation of $\mathrm{H}_{\mathrm{a}}($ wt. $\% \mathrm{H})$ with $\mathrm{t}(\mathrm{min})$ at $573 \mathrm{~K}$ in 12 bar $\mathrm{H}_{2}$ at $\mathrm{n}=1 \sim 4$ for $85 \mathrm{MgH}_{2}+15 \mathrm{Ti}$

\begin{tabular}{|c|c|c|c|c|c|}
\hline & $2.5 \min$ & $5 \min$ & $10 \min$ & $30 \min$ & $60 \min$ \\
\hline $\mathrm{n}=1$ & 1.58 & 2.17 & 2.67 & 3.26 & 3.44 \\
\hline $\mathrm{n}=2$ & 1.49 & 20.08 & 2.58 & 3.21 & 3.35 \\
\hline $\mathrm{n}=3$ & 1.58 & 2.17 & 2.68 & 3.25 & 3.48 \\
\hline $\mathrm{n}=4$ & 1.40 & 1.99 & 2.44 & 3.02 & 3.21 \\
\hline
\end{tabular}

We define the quantity of hydrogen absorbed for $60 \mathrm{~min}$ as the effective hydrogen storage capacity. $85 \mathrm{MgH}_{2}+15 \mathrm{Ti}$ has an effective hydrogen-storage capacity of 3.44 wt. $\%$ at $573 \mathrm{~K}$ in 12 bar $\mathrm{H}_{2}$ at $\mathrm{n}=1$. The variation in $\mathrm{H}_{\mathrm{d}}$ versus $\mathrm{t}$ curve with cycle number, $\mathrm{n}$, at $573 \mathrm{~K}$ in 1.0 bar $\mathrm{H}_{2}$ for $85 \mathrm{MgH}_{2}+15 \mathrm{Ti}$ is shown in Fig. 2. At $\mathrm{n}=1$, the initial dehydriding rate is slightly high and the quantity of hydrogen released for $60 \mathrm{~min}, \mathrm{H}_{\mathrm{d}}(60 \mathrm{~min})$, is small.

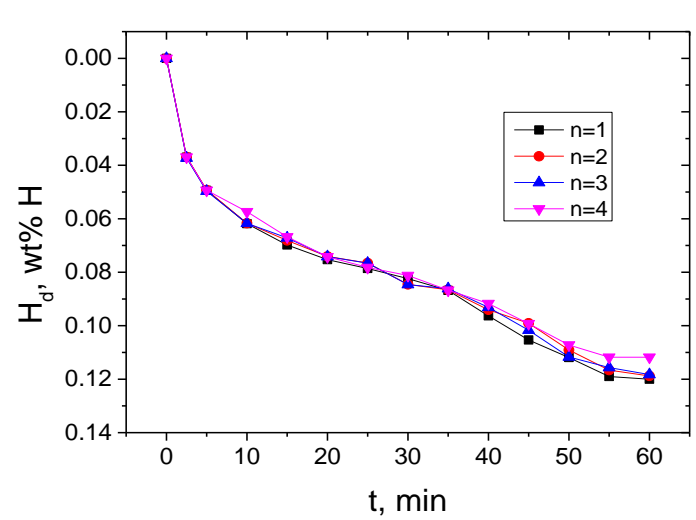

Fig. 2. Variation in $\mathrm{H}_{d}$ versus $t$ curve with cycle number, $n$, at $573 \mathrm{~K}$ in 1.0 bar $\mathrm{H}_{2}$ for $85 \mathrm{MgH}_{2}+15 \mathrm{Ti}$

The slightly high initial dehydriding rate is believed to be due to the slightly large quantities of hydrogen desorbed from the surfaces of the particles and released from the $\mathrm{Mg}-\mathrm{H}$ solid solution. As $\mathrm{n}$ increases from one to four, the initial dehydriding rates are the same and $\mathrm{H}_{\mathrm{d}}(60 \mathrm{~min})$ decreases. The general decrease in the $\mathrm{H}_{\mathrm{d}}(60 \mathrm{~min})$ with the increase in the cycle number is believed to be due to coalescence of particles since the sample was maintained at the relatively high temperature $573 \mathrm{~K}$ during hydridingdehydriding cycling. At $\mathrm{n}=1,85 \mathrm{MgH}_{2}+15 \mathrm{Ti}$ releases $0.04 \mathrm{wt} \% \mathrm{H}$ for $2.5 \mathrm{~min}, 0.06 \mathrm{wt} . \% \mathrm{H}$ for $10 \mathrm{~min}$, and 0.12 wt. $\% \mathrm{H}$ for $60 \mathrm{~min}$. At $\mathrm{n}=4,85 \mathrm{MgH}_{2}+15 \mathrm{Ti}$ releases $0.0 .04 \mathrm{wt} \% \mathrm{H}$ for $2.5 \mathrm{~min}, 0.06 \mathrm{wt} \% \mathrm{H}$ for $10 \mathrm{~min}$, and $0.11 \mathrm{wt} . \% \mathrm{H}$ for $60 \mathrm{~min}$. Table 2 shows the

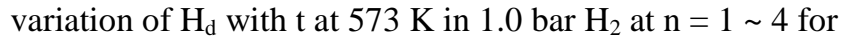
$85 \mathrm{MgH}_{2}+15 \mathrm{Ti}$.

Table 2. Variation of $\mathrm{H}_{\mathrm{d}}(\mathrm{wt} . \% \mathrm{H})$ with $\mathrm{t}(\mathrm{min})$ at $573 \mathrm{~K}$ in 1.0 bar $\mathrm{H}_{2}$ at $\mathrm{n}=1 \sim 4$ for $85 \mathrm{MgH}_{2}+15 \mathrm{Ti}$

\begin{tabular}{|c|c|c|c|c|c|}
\hline & $2.5 \min$ & $5 \min$ & $10 \min$ & $30 \min$ & $60 \min$ \\
\hline $\mathrm{n}=1$ & 0.04 & 0.05 & 0.06 & 0.08 & 0.12 \\
\hline $\mathrm{n}=2$ & 0.04 & 0.05 & 0.06 & 0.08 & 0.12 \\
\hline $\mathrm{n}=3$ & 0.04 & 0.05 & 0.06 & 0.08 & 0.12 \\
\hline $\mathrm{n}=4$ & 0.04 & 0.05 & 0.06 & 0.08 & 0.11 \\
\hline
\end{tabular}

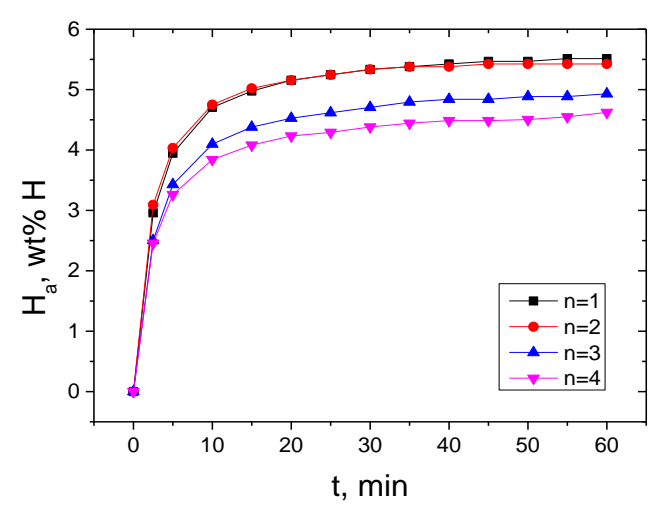

Fig. 3. Variation in $\mathrm{H}_{\mathrm{a}}$ versus $\mathrm{t}$ curve with cycle number at $593 \mathrm{~K}$ in 12 bar $\mathrm{H}_{2}$ for $85 \mathrm{MgH}_{2}+15 \mathrm{Ti}$

Fig. 3 shows the variation in $\mathrm{H}_{\mathrm{a}}$ versus $\mathrm{t}$ curve with cycle number, $\mathrm{n}$, at $593 \mathrm{~K}$ in $12 \mathrm{bar} \mathrm{H}_{2}$ for $85 \mathrm{MgH}_{2}+15 \mathrm{Ti}$. At $\mathrm{n}=1$, the initial hydriding rate is quite high and the $\mathrm{H}_{\mathrm{a}}(60 \mathrm{~min})$ is quite large. The hydriding rate decreases gradually as the reaction time elapses and is 
very low after $20 \mathrm{~min}$. As $\mathrm{n}$ increases from one to four, the initial hydriding rate decreases in general and the $\mathrm{H}_{\mathrm{a}}$ (60 min) decreases. At $\mathrm{n}=1,85 \mathrm{MgH}_{2}+15 \mathrm{Ti}$ absorbs $2.96 \mathrm{wt} . \% \mathrm{H}$ for $2.5 \mathrm{~min}, 4.70 \mathrm{wt} . \% \mathrm{H}$ for $10 \mathrm{~min}$, and 5.51 wt. $\% \mathrm{H}$ for $60 \mathrm{~min}$. At $\mathrm{n}=4,85 \mathrm{MgH}_{2}+15 \mathrm{Ti}$ absorbs $2.46 \mathrm{wt} . \% \mathrm{H}$ for $2.5 \mathrm{~min}, 3.84 \mathrm{wt} . \% \mathrm{H}$ for $10 \mathrm{~min}$, and $4.62 \mathrm{wt} . \% \mathrm{H}$ for $60 \mathrm{~min}$. Table 3 shows the variation of $\mathrm{H}_{\mathrm{a}}$ with $\mathrm{t}$ at $593 \mathrm{~K}$ in 12 bar $\mathrm{H}_{2}$ at $\mathrm{n}=1 \sim 4$ for $85 \mathrm{MgH}_{2}+15 \mathrm{Ti}$. The initial hydriding rate is higher and the $\mathrm{H}_{\mathrm{a}}(60 \mathrm{~min})$ is larger at $593 \mathrm{~K}$ than those at $573 \mathrm{~K}$.

Table 3. Variation of $\mathrm{H}_{\mathrm{a}}($ wt. $\% \mathrm{H})$ with $\mathrm{t}(\mathrm{min})$ at $593 \mathrm{~K}$ in 12 bar $\mathrm{H}_{2}$ at $\mathrm{n}=1 \sim 4$ for $85 \mathrm{MgH}_{2}+15 \mathrm{Ti}$

\begin{tabular}{|c|c|c|c|c|c|}
\hline & $2.5 \min$ & $5 \min$ & $10 \min$ & $30 \min$ & $60 \min$ \\
\hline $\mathrm{n}=1$ & 2.96 & 3.94 & 4.70 & 5.33 & 5.51 \\
\hline $\mathrm{n}=2$ & 3.09 & 4.03 & 4.75 & 5.33 & 5.42 \\
\hline $\mathrm{n}=3$ & 2.50 & 3.42 & 4.09 & 4.70 & 4.93 \\
\hline $\mathrm{n}=4$ & 2.46 & 3.26 & 3.84 & 4.38 & 4.62 \\
\hline
\end{tabular}

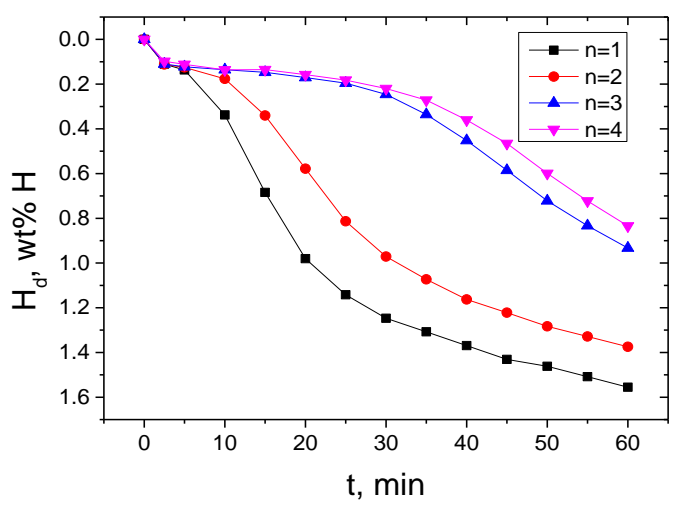

Fig. 4. Variation in $\mathrm{H}_{d}$ versus $t$ curve with cycle number at $593 \mathrm{~K}$ in 1 bar $\mathrm{H}_{2}$ for $85 \mathrm{MgH}_{2}+15 \mathrm{Ti}$

The variation in $\mathrm{H}_{\mathrm{d}}$ versus $\mathrm{t}$ curve with cycle number, $\mathrm{n}$, at $593 \mathrm{~K}$ in 1.0 bar $\mathrm{H}_{2}$ for $85 \mathrm{MgH}_{2}+15 \mathrm{Ti}$ is shown in Fig. 4. At $\mathrm{n}=1$, the initial dehydriding rate is slightly high and the $\mathrm{H}_{\mathrm{d}}(60 \mathrm{~min})$ is larger, compared with those at $573 \mathrm{~K}$. As $\mathrm{n}$ increases from one to four, the initial dehydriding rate decreases slightly and $H_{d}(60 \mathrm{~min})$ decrease. At $2.5 \mathrm{~min}$, the dehydriding rates are low. The dehydriding rates increase gradually after $2.5 \mathrm{~min}$ and are quite high at $10 \mathrm{~min}$ at $\mathrm{n}=1,15 \mathrm{~min}$ at $\mathrm{n}=2$, and $45 \mathrm{~min}$ at $\mathrm{n}=3$ and $\mathrm{n}=4$. At $\mathrm{n}=1,85 \mathrm{MgH}_{2}+15 \mathrm{Ti}$ releases $0.11 \mathrm{wt} . \% \mathrm{H}$ for $2.5 \mathrm{~min}, 0.34 \mathrm{wt} . \% \mathrm{H}$ for $10 \mathrm{~min}$, and 1.56 wt. $\% \mathrm{H}$ for $60 \mathrm{~min}$. At $\mathrm{n}=4,85 \mathrm{MgH}_{2}+15 \mathrm{Ti}$ releases $0.09 \mathrm{wt} . \% \mathrm{H}$ for $2.5 \mathrm{~min}, 0.14 \mathrm{wt} . \% \mathrm{H}$ for $10 \mathrm{~min}$, and $0.83 \mathrm{wt} . \% \mathrm{H}$ for $60 \mathrm{~min}$. Table 4 shows the variation of $\mathrm{H}_{\mathrm{d}}$ with $\mathrm{t}$ at $593 \mathrm{~K}$ in 1.0 bar $\mathrm{H}_{2}$ at $\mathrm{n}=1 \sim 4$ for $85 \mathrm{MgH}_{2}+15 \mathrm{Ti}$.

Table 4. Variation of $\mathrm{H}_{\mathrm{d}}(\mathrm{wt} . \% \mathrm{H})$ with $\mathrm{t}(\mathrm{min})$ at $593 \mathrm{~K}$ in $1.0 \mathrm{bar}$ $\mathrm{H}_{2}$ at $\mathrm{n}=1 \sim 4$ for $85 \mathrm{MgH}_{2}+15 \mathrm{Ti}$

\begin{tabular}{|c|c|c|c|c|c|}
\hline & $2.5 \min$ & $5 \min$ & $10 \min$ & $30 \min$ & $60 \min$ \\
\hline $\mathrm{n}=1$ & 0.11 & 0.14 & 0.34 & 1.25 & 1.56 \\
\hline $\mathrm{n}=2$ & 0.11 & 0.13 & 0.18 & 0.97 & 1.37 \\
\hline $\mathrm{n}=3$ & 0.11 & 0.12 & 0.14 & 0.25 & 0.93 \\
\hline $\mathrm{n}=4$ & 0.09 & 0.11 & 0.14 & 0.22 & 0.83 \\
\hline
\end{tabular}

The initial dehydriding rate is higher and $\mathrm{H}_{\mathrm{d}}(60 \mathrm{~min})$ is larger at $593 \mathrm{~K}$ than those at $573 \mathrm{~K}$, probably because the temperature is higher and the difference between the equilibrium plateau pressure of $\mathrm{Mg}-\mathrm{H}$ system and the applied hydrogen pressure $\left(1.0\right.$ bar $\left.\mathrm{H}_{2}\right)$ at $593 \mathrm{~K}$ is larger than that at $573 \mathrm{~K}$.

Fig. 1-Fig. 4 show that the activation of $85 \mathrm{MgH}_{2}+15 \mathrm{Ti}$ is not necessary. However, the cycling performance of $85 \mathrm{MgH}_{2}+15 \mathrm{Ti}$ is not good. Studies to improve the cycling performance of $85 \mathrm{MgH}_{2}+15 \mathrm{Ti}$ are going to be performed in our future work.

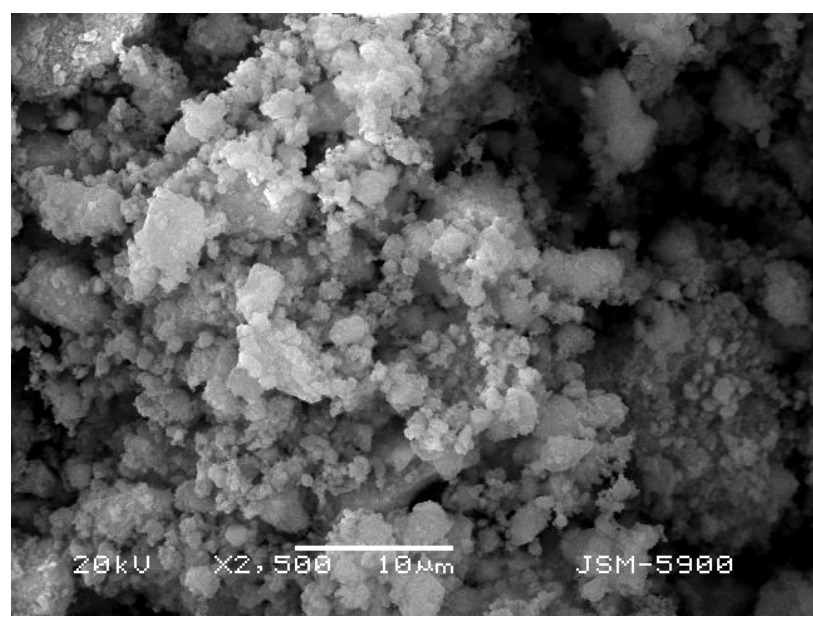

Fig. 5. A SEM micrograph of $85 \mathrm{MgH}_{2}+15 \mathrm{Ti}$ after reactive mechanical grinding

Fig. 5 shows a SEM micrograph of $85 \mathrm{MgH}_{2}+15 \mathrm{Ti}$ after reactive mechanical grinding. Particle size is not homogeneous; some particles are fine and some particles are large. These particles form agglomerates.

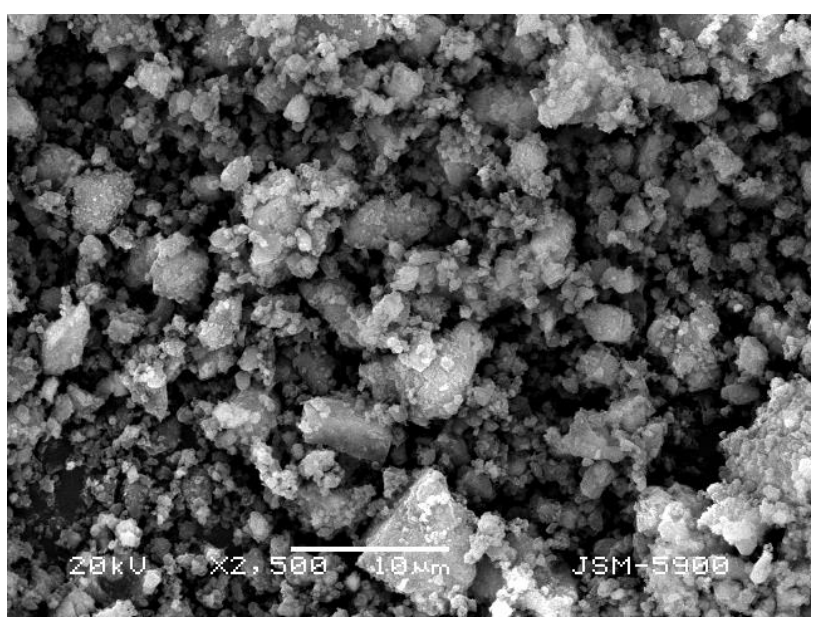

Fig. 6. A SEM micrograph of $85 \mathrm{MgH}_{2}+15 \mathrm{Ti}$ dehydrided in 1.0 bar $\mathrm{H}_{2}$ at $\mathrm{n}=4$

A SEM micrograph of $85 \mathrm{MgH}_{2}+15 \mathrm{Ti}$ dehydrided in 1.0 bar $\mathrm{H}_{2}$ at $\mathrm{n}=4$ is shown in Fig. 6. Particle size is not homogeneous, either; some particles are fine and some particles are large. These particles form agglomerates. Particles and agglomerates are smaller than those of the sample after reactive mechanical grinding, probably due to pulverization of the particles owing to expansion (by hydriding reaction) and contraction (by dehydriding reaction) with hydriding-dehydriding cycling [23-28].

Fig. 7 shows the XRD pattern of $85 \mathrm{MgH}_{2}+15 \mathrm{Ti}$ after reactive mechanical grinding. The $85 \mathrm{MgH}_{2}+15 \mathrm{Ti}$ after reactive mechanical grinding contains a large amount 
of $\beta-\mathrm{MgH}_{2}$ and small amounts of $\mathrm{Mg}, \gamma-\mathrm{MgH}_{2}, \mathrm{TiH}_{1.924}$, $\mathrm{MgO}$, and $\mathrm{MgTi}_{2} \mathrm{O}_{4}$. This shows that $\mathrm{TiH}_{1.924}$ is formed by the reaction of $\mathrm{Ti}$ with hydrogen during milling in hydrogen. Huot et al. [29] reported that the synthesis of magnesium hydride by reactive ball milling leads to the formation of a metastable orthorhombic $\gamma-\mathrm{MgH}_{2}$ phase along with tetragonal $\beta-\mathrm{MgH}_{2}$.

The XRD pattern of $85 \mathrm{MgH}_{2}+15 \mathrm{Ti}$ dehydrided in 1.0 bar $\mathrm{H}_{2}$ at $\mathrm{n}=4$ is shown in Fig. 8. The $85 \mathrm{MgH}_{2}+15 \mathrm{Ti}$ dehydrided in 1.0 bar $\mathrm{H}_{2}$ at the $4^{\text {th }}$ hydriding-dehydriding cycle contains large amounts of $\beta$ $\mathrm{MgH}_{2}$ and $\mathrm{Mg}$ and very small amounts of $\mathrm{MgO}, \mathrm{MgTi}_{2} \mathrm{O}_{4}$, $\mathrm{TiH}_{1.924}$, and $\mathrm{Mg}(\mathrm{OH})_{2}$. $\mathrm{TiH}_{1.924}$ remains undecomposed, but $\gamma-\mathrm{MgH}_{2}$ disappeared, after the sample was dehydrided in 1.0 bar $\mathrm{H}_{2}$ at $\mathrm{n}=4 . \mathrm{MgTi}_{2} \mathrm{O}_{4}$ and $\mathrm{MgO}$ are believed to be formed by the reaction with oxygen adsorbed on the particle surfaces during treating the samples to obtain the XRD pattern. $\operatorname{Mg}(\mathrm{OH})_{2}$ is believed to be formed by the reaction with water vapor adsorbed on the particle surfaces during treating the samples to obtain the XRD pattern.

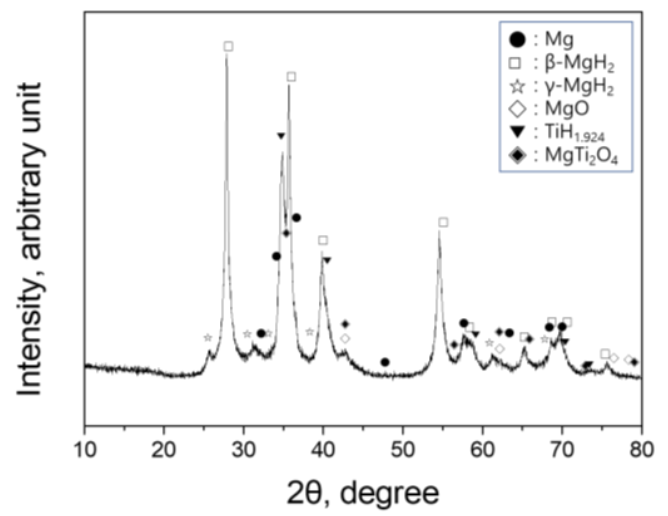

Fig. 7. XRD pattern of $85 \mathrm{MgH}_{2}+15 \mathrm{Ti}$ after reactive mechanical grinding

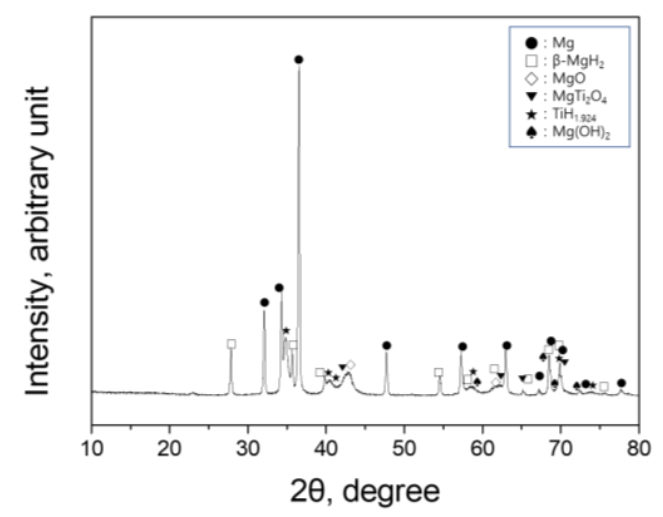

Fig. 8. XRD pattern of $85 \mathrm{MgH}_{2}+15 \mathrm{Ti}$ dehydrided in 1.0 bar $\mathrm{H}_{2}$ at $n=4$

Reactive mechanical grinding of $\mathrm{MgH}_{2}$ with $\mathrm{Ti}$ is believed to create defects (leading to facilitation of nucleation), produce cracks and clean surfaces (leading to increase in reactivity), and decrease particle sizes (leading to diminution of diffusion distances or increasing the flux of the diffusing hydrogen atoms) [30-36]. Decrease in the particle sizes leads to the increase in the specific surface area of the sample. The $\beta-\mathrm{MgH}_{2}, \gamma-\mathrm{MgH}_{2}, \mathrm{TiH}_{1.924}, \mathrm{MgO}$, and $\mathrm{MgTi}_{2} \mathrm{O}_{4}$ formed during reactive mechanical grinding and their pulverization during reactive mechanical grinding are believed to make these effects stronger. The hydridingdehydriding cycling is also believed to create defects, produce cracks and clean surfaces, and decrease particle sizes due to expansion (by hydriding reaction) and contraction (by dehydriding reaction) of $\mathrm{Mg}$ [37-42]. These effects of reactive mechanical grinding and hydriding-dehydriding cycling are believed to have improved the hydriding and dehydriding features of $\mathrm{MgH}_{2}$.

\section{CONCLUSIONS}

Titanium was chosen as an additive to improve the hydriding and dehydriding features of $\mathrm{MgH}_{2} .15$ wt.\% Ti was added to $\mathrm{MgH}_{2}$ by reactive mechanical grinding. At the first cycle, $85 \mathrm{MgH}_{2}+15 \mathrm{Ti}$ absorbed $2.96 \mathrm{wt} . \% \mathrm{H}$ for $2.5 \mathrm{~min}$ and $5.51 \mathrm{wt} . \% \mathrm{H}$ for $60 \mathrm{~min}$ at $593 \mathrm{~K}$ in 12 bar $\mathrm{H}_{2}$, having an effective hydrogen-storage capacity of 5.51 wt.\%. $85 \mathrm{MgH}_{2}+15 \mathrm{Ti}$ released $0.11 \mathrm{wt} \% \mathrm{H}$ for $2.5 \mathrm{~min}$ and $1.56 \mathrm{wt} . \% \mathrm{H}$ for $60 \mathrm{~min}$ at $593 \mathrm{~K}$ in $1.0 \mathrm{bar}_{2}$ at $\mathrm{n}=1$. Reactive mechanical grinding of $\mathrm{MgH}_{2}$ with Ti is believed to create defects, produce cracks and clean surfaces, and decrease particle sizes. The $\beta-\mathrm{MgH}_{2}, \gamma-\mathrm{MgH}_{2}$, $\mathrm{TiH}_{1.924}, \mathrm{MgO}$, and $\mathrm{MgTi}_{2} \mathrm{O}_{4}$ formed during reactive mechanical grinding and their pulverization during reactive mechanical grinding are believed to make these effects stronger. The hydriding-dehydriding cycling is also believed to bring about the effects similar to those of reactive mechanical grinding.

\section{Acknowledgements}

This research was supported by Basic Science Research Program through the National Research Foundation of Korea (NRF) funded by the Ministry of Education (grant number NRF2017R1D1A1B03030515).

\section{REFERENCES}

1. Krozer, A., Kasemo, B. Equilibrium Hydrogen Uptake and Associated Kinetics for the $\mathrm{Mg}-\mathrm{H}_{2}$ System at Low Pressures Journal of Physics: Condensed Matter 1(8) 1989: pp. $1533-1538$. https://doi.org/10.1088/0953-8984/1/8/017

2. Karty, A., Genossar, J.G., Rudman, P.S. Hydriding and Dehydriding Kinetics of $\mathrm{Mg}$ in a $\mathrm{Mg} / \mathrm{Mg}_{2} \mathrm{Cu}$ Eutectic Alloy: Pressure Sweep Method Journal of Applied Physics 50 (11) 1979: pp. $7200-7209$. https://doi.org/10.1063/1.325832

3. Bobet, J.L. Akiba, E., Nakamura, Y., Darriet, B. Study of $\mathrm{Mg}-\mathrm{M}(\mathrm{M}=\mathrm{Co}, \mathrm{Ni}$ and $\mathrm{Fe}$ ) Mixture Elaborated by Reactive Mechanical Alloying-Hydrogen Sorption Properties International Journal of Hydrogen Energy 25 (10) 2000: pp. $987-996$. https://doi.org/10.1016/S0360-3199(00)00082-3

4. Reilly, J.J., Wiswall, R.H. Reaction of Hydrogen with Alloys of Magnesium and Copper Inorganic Chemistry 7 (11) 1968: pp. 2254-2256. https://doi.org/10.1021/ic50058a020

5. Tran, N.E., Imam, M.A., Feng, C.R. Evaluation of Hydrogen Storage Characteristics of Magnesium-Misch Metal Alloys Journal of Alloys Compounds $359(1-2)$ 2003: pp. $225-229$. https://doi.org/10.1016/S0925-8388(03)00176-2 
6. Huot, J., Tremblay, M.L., Schulz, R. Synthesis of Nanocrystalline Hydrogen Storage Materials Journal of Alloys Compounds 356-357 2003: pp. 603-607. https://doi.org/10.1016/S0925-8388(03)00120-8

7. Popilevsky, L., Skripnyuk, V.M., Beregovsky, M., Senzen, M., Amouyal, Y., Rabkin, E. Hydrogen Storage and Thermal Transport Properties of Pelletized Porous Mg-2 wt.\% Multiwall Carbon Nanotubes and Mg-2 wt.\% Graphite Composites International Journal of Hydrogen Energy 41 (32) 2016: pp. $14461-14474$.

https://doi.org/10.1016/j.ijhydene.2016.03.014

8. Guoxian, L., Erde, W., Shoushi, F. Hydrogen Absorption and Desorption Characteristics of Mechanically Milled Mg35 wt.\% FeTi 1.2 Powders Journal of Alloys Compounds 223 (1) 1995: pp. $111-114$.

https://doi.org/10.1016/0925-8388(94)01465-5

9. Liang, G., Boily, S., Huot, J., Neste, A.V., Schulz, R. Hydrogen Absorption Properties of a Mechanically Milled $\mathrm{Mg}-50$ wt.\% LaNi5 Composite Journal of Alloys Compounds $268(1-2)$ 1998: pp. 302-307. https://doi.org/10.1016/S0925-8388(97)00607-5

10. Khrussanova, M., Bobet, J.L., $\quad$ Terzieva, M., Chevalier, B., Radev, D., Peshev, P., Darriet, B. Hydrogen Storage Characteristics of Magnesium Mechanically Alloyed with $\mathrm{YNi}_{5}-\mathrm{xAlx} \quad(\mathrm{x}=0, \quad 1 \quad$ and 3$)$ Intermetallics Journal of Alloys Compounds $307(1-2)$ 2000: pp. $283-289$.

https://doi.org/10.1016/S0925-8388(00)00842-2

11. Rizo-Acosta, P., Cuevas, F., Latroche, M. Optimization of $\mathrm{TiH}_{2}$ Content for Fast and Efficient Hydrogen Cycling of $\mathrm{MgH}_{2}-\mathrm{TiH}_{2}$ Nanocomposites International Journal of Hydrogen Energy 43 2018: pp. 16774-16781. https://doi.org/10.1016/j.ijhydene.2018.04.169

12. Sohn, H.Y., Emami, S. Kinetics of Dehydrogenation of the $\mathrm{Mg}$-Ti-H Hydrogen Storage System International Journal of Hydrogen Energy 36 2011: pp. 8344-8350. https://doi.org/10.1016/j.ijhydene.2011.03.167

13. Daryani, M., Simchi, A., Sadati, M., Mdaah Hosseini, H., Targholizadeh, H., Khakbiz, M. Effects of Ti-Based Catalysts on Hydrogen Desorption Kinetics of Nanostructured Magnesium Hydride International Journal of Hydrogen Energy 39 2014: pp. 21007-21014. https://doi.org/10.1016/j.ijhydene.2014.10.078

14. Kwak, Y.J., Park, H.R., Song, M.Y. Characterization of Hydrogen-Storage Properties and Physical Properties of Zinc Borohydride and Transition Metals-Added Magnesium Hydride Materials Science (Medžiagotyra) 23 (1) 2017: pp. 31-38.

http://dx.doi.org/10.5755/j01.ms.23.1.14878

15. Song, M.Y., $\quad$ Lee, S.H., $\quad$ Kwak, Y.J., Park, H.R. Improvement in Hydrogention and Dehydrogenation Characteristics of Magnesium by Addition of Titanium (III) Chloride via Transformation-Accompanying Milling Materials Science (Medžiagotyra) 23 (3) 2017: pp. 227-232. http://dx.doi.org/10.5755/j01.ms.23.3.16375

16. Park, H.R., Lee, S.H., Kwak, Y.J., Song, M.Y. Oxide or Halide and Nickel-Added $\mathrm{Mg}$ by Phase TransitionAccompanying High-energy Ball Milling Processing Journal of Ceramic Processing Research 18 (11) 2017: pp. 824-830.

17. Kwak, Y.J., Song, M.Y. How to Analyse Metal Hydride Decomposition Temperatures Using a Sieverts' Type Hydriding-Dehydriding Apparatus and Hydrogen-Storage Characteristics for an $\mathrm{MgH}_{2}$-Based Alloy Materials Science (Medžiagotyra) 24 (1) 2018: pp. 24-28. http://dx.doi.org/10.5755/j01.ms.24.1.17664

18. Choi, E., Kwak, Y.J., Song, M.Y. Development of an MgBased Alloy with a Hydrogen-Storage Capacity over 6 wt\% by Adding Graphene Metals and Materials International 24 (6) 2018: pp. $1403-1411$.

https://doi.org/10.1007/s12540-018-0151-2

19. Kwak, Y.J., Park, H.R., Song, M.Y. Advancement in the Hydrogen Absorbing and Releasing Kinetics of $\mathrm{MgH}_{2}$ by Mixing with Small Percentages of $\mathrm{Zn}\left(\mathrm{BH}_{4}\right)_{2}$ and $\mathrm{Ni}$ Metals and Materials International 22 (2) 2018: pp. 423-432. https://doi.org/10.1007/s12540-018-0036-4

20. Park, H.R., Kwon, S.N., Song, M.Y. Effects of Milling Ttime on the Hydrogen Storage Properties of Mg-Based Transition Metals-Added Alloys Materials Science (Medžiagotyra) 24 (2) 2018: pp. 166-71. http://dx.doi.org/10.5755/j01.ms.24.2.18395

21. Kwak, Y.J., Park, H.R., Song, M.Y. Changes in Microstructure, Phases, and Hydrogen Storage Characteristics of Metal Hydro-Borate and Nickel-Added Magnesium Hydride with Hydrogen Absorption and Release Reactions International Journal of Hydrogen Energy 42 (2) 2017: pp. $1018-1026$.

https://doi.org/10.1016/j.ijhydene.2016.10.097

22. Song, M.Y., Choi, E., Kwak, Y.J. Development of a MgBased Alloy with a Hydrogen-Storage Capacity of 7 wt.\% by Adding a Polymer CMC via Transformation-Involving Milling Korean Journal of Metals and Materials $56(5)$ 2018: pp. $392-399$ https://doi.org/10.3365/KJMM.2018.56.5.392

23. Song, M.Y., Kwak, Y.J., Lee, S.H., Park, H.R. Increase in Hydrogen Release Rate of $\mathrm{MgH}_{2}$ by Grinding in a Hydrogen Atmosphere with Ni Added Journal of Nanoscience and Nanotechnology 16 2016: pp. $10499-10507$.

https://doi.org/10.1166/jnn.2016.13184

24. Kwak, Y.J., Lee, S.H., Park, H.R., Song, M.Y. Hydrogen Storage Characteristics of $\mathrm{Mg}, \mathrm{Mg}-5 \mathrm{TaF}_{5}$, and $\mathrm{Mg}-5 \mathrm{NbF}_{5}$ Prepared via Grinding in a Hydrogen Atmosphere Journal of Nanoscience and Nanotechnology 16 2016: pp. $10508-10514$.

https://doi.org/10.1166/jnn.2016.13185

25. Kwak, Y.J., Park, H.R., Song, M.Y. Development of a Hydrogen-Storage Alloy with a High Capacity of Approximately 6 wt. $\%$ by Adding a Transition Metal and a Halide Journal of Nanoscience and Nanotechnology 17 (11) 2017: pp. 8105-8111. https://doi.org/10.1166/jnn.2017.15083

26. Song, M.Y., Lee, S.H., Kwak, Y.J., Park, H.R. Cycling Performance of $\mathrm{NaAlH}_{4}$ and Transition Metals-Added $\mathrm{MgH}_{2}$ Prepared via Milling in a Hydrogen Atmosphere Journal of Nanoscience and Nanotechnology 17 (11) 2017: pp. $8132-8137$. https://doi.org/10.1166/jnn.2017.15084

27. Kwak, Y.J., Lee, S.H., Song, M.Y. Development of an MgBased Alloy with High Hydriding and Dehydriding Rates and a Large Hydrogen Storage Capacity by Adding $\mathrm{TaF}_{5}$ Journal Nanoscience and Nanotechnology 18(9) 2018: pp. $6040-6046$. https://doi.org/10.1166/jnn.2018.15607

28. Song, M.Y., Kwak, Y.J., Lee, S.H. Improvement of Hydrogen-Storage Characteristics of Magnesium Hydride by Grinding with Sodium Alanate and Transition Metals in Hydrogen Atmosphere Journal Nanoscience and Nanotechnology 18 (9) 2018: pp. 6047-6054. https://doi.org/10.1166/jnn.2018.15608 
29. Huot, J., Swainson, I., Schulz, R. Changement de Phase Induit par Broyage Mecanique dans l'Hydrure de Magesium (Phase Transformation in Magnesium Hydride Induced by Ball Milling) Annales de Chimie Science des Materiaux (Paris) 31 (1) 2006: pp. 135-144.

30. Park, H.R., Kwak, Y.J., Song, M.Y. Increase in the Hydrogen-Sorption Rates and Hydrogen-Storage Capacity of $\mathrm{MgH}_{2}$ by Adding a Small Proportion of $\mathrm{Zn}\left(\mathrm{BH}_{4}\right)_{2}$ Korean Journal of Metals and Materials 55 (9) 2017: pp. 656-662. https://doi.org/10.3365/KJMM.2017.55.9.657

31. Hong, S.H., Kwak, Y.J., Song, M.Y. Enhancement of the Hydrogen-Storage Characteristics of $\mathrm{Mg}$ by Adding $\mathrm{Mg}_{2} \mathrm{Ni}$ and $\mathrm{Ni}$ to $\mathrm{MgH}_{2}$ via High Energy Ball Milling in Hydrogen Atmosphere Korean Journal of Metals and Materials 56 (1) 2018: pp. 59-65. https://doi.org/10.3365/KJMM.2018.56.1.59

32. Hong, S.H., Song, M.Y. Hydrogen Absorption and Release Properties of $\mathrm{MgH}_{2}, \mathrm{Mg}_{2} \mathrm{Ni}$, and Ni-added $\mathrm{Mg}$ via Reactive Mechanical Grinding Korean Journal of Metals and Materials $56(2)$ 2018: pp. 155-162.

https://doi.org/10.3365/KJMM.2018.56.2.141

33. Song, M.Y., Kwak, Y.J. Comparison of the Hydrogen Release Properties of $\mathrm{Zn}\left(\mathrm{BH}_{4}\right)_{2}$-Added $\mathrm{MgH}_{2}$ Alloy and $\mathrm{Zn}\left(\mathrm{BH}_{4}\right)_{2}$ and $\mathrm{Ni}$-added $\mathrm{MgH}_{2}$ Alloy Korean Journal of Metals and Materials 56 (3) 2018: pp. 244-251. https://doi.org/10.3365/KJMM.2018.56.3.244

34. Song, M.Y., Kwak, Y.J. Hydrogen Uptake and Release Characteristics of $\mathrm{Mg}-\mathrm{xTaF}_{5}-\mathrm{xVCl}_{3}(\mathrm{x}=1.25,2.5$, and 5) Korean Journal of Metals and Materials $56(8)$ 2018: pp. $611-619$. https://doi.org/10.3365/KJMM.2018.56.8.611

35. Song, M.Y., Choi, E., Kwak, Y.J. Raising the Dehydrogenation Rate of a Mg-CMC (Carboxymethylcellulose, Sodium Salt) Composite by Alloying Ni via Hydride-Forming Milling Korean Journal of Metals and Materials $56(8)$ 2018: pp. 620-627. https://doi.org/10.3365/KJMM.2018.56.8.620
36. Choi, E., Kwak, Y.J., Song, M.Y. Development of an MgBased Alloy with a Hydrogen-Storage Capacity over 6 wt\% by Adding Graphene Metals and Materials International 24 (6) 2018: pp. $1403-1411$.

https://doi.org/10.1007/s12540-018-0151-2

37. Park, H.R., Kwak, Y.J., Song, M.Y. Role of the added Ni in Hydrogen-Storage Reactions of $\mathrm{MgH}_{2}-\mathrm{Zn}\left(\mathrm{BH}_{4}\right)_{2}-\mathrm{Tm}(\mathrm{Ni}$, Ti, or Fe) Alloys Material Science 24(4) 2018: pp. 376-381. http://dx.doi.org/10.5755/j01.ms.24.4.19051

38. Song, M.Y., Kwak, Y.J. Hydrogen Storage Properties of $\mathrm{Mg}$ Alloy Prepared by Incorporating Polyvinylidene fluoride via Reactive Milling Korean Journal of Metals and Materials 56(12) 2018: pp. 878-884. https://doi.org/10.3365/KJMM.2018.56.12.878

39. Song, M.Y., Kwak, Y.J., Lee, S.H., $\quad$ Park, H.R. Development of Mg-14Ni-6TaF5 Hydrogen AbsorptionDesorption Material via Reactive Mechanical Grinding Materials Science (Medžiagotyra) 20 (4) 2014: pp. $440-445$. https://doi.org/10.5755/j01.ms.20.4.6457

40. Song, M.Y., Kwon, S.N., Park, H.R. Addition of Oxides $\mathrm{Fe}_{2} \mathrm{O}_{3}$ and/or $\mathrm{MnO}$ to Improve Hydrogen Storage Properties of Magnesium by Reaction-Involved Milling Journal of Ceramic Processing Research 17 (8) 2016: pp. 851-857.

41. Park, H.R., Lee, S.H., Song, M.Y. Comparison of the Hydrogenation and Dehydrogenation Properties of Oxide and Halide-Added Mg Composites Prepared by Reactive Mechanical Grinding and Characterization of an $\mathrm{Mg}^{-\mathrm{TiCl}_{3}}$ Composite Journal of Ceramic Processing Research 17 (12) 2016: pp. $1292-1298$.

42. Kwak, Y.J., Park, H.R., Song, M.Y. Analysis of the Metal hydride Decomposition Temperatures of $\mathrm{MgH}_{2}-\mathrm{Zn}\left(\mathrm{BH}_{4}\right)_{2}$ $-\mathrm{NaCl}-\mathrm{Tm}(\mathrm{Tm}=\mathrm{Ni}$ or Ti) Using a Sievert's Type Volumetric Apparatus Materials Science (Medžiagotyra) 23 (1) 2017: pp. $21-26$ https://dx.doi.org/10.5755/j01.ms.23.1.14270 